\title{
Transgenic Arabidopsis thaliana and Nicotiana tabacum overexpressing the Eucalyptus grandis Cellulose Synthase 3 and its expression pattern in different Eucalyptus species and tissues
}

\author{
Wesley L Marques ${ }^{1 *}$, Marcela Salazar ${ }^{1 *}$, Eduardo Camargo $^{1 *}$, Jorge Lepikson-Neto ${ }^{1 *}$, Danieli Cristina Gonçalves ${ }^{1 *}$, \\ Leandro Costa do Nascimento ${ }^{1 *}$, Carla Garcia ${ }^{2 *}$, Adriano Almeida ${ }^{2^{*}}$, Gonçalo Pereira ${ }^{1^{*}}$
}

From IUFRO Tree Biotechnology Conference 2011: From Genomes to Integration and Delivery Arraial d'Ajuda, Bahia, Brazil. 26 June - 2 July 2011

\section{Background}

In Brazil, the forest industry accounts for 4,5\% from the Gross Domestic Product and the country is the biggest Eucalyptus cellulose exporter. That's really good news because Eucalyptus forests are a competitive and efficient alternative to convert carbon from the atmosphere in cellulose, an important source for paper and bioenergy production.

The cellulose biosynthesis happens through the Cellulose Synthase Complex activity. This complex is composed by different Cellulose Synthase genes (CesA) that work together in a non redundant way [1]. It is also known that some of these isoforms act in the primary cell wall synthesis while others, in the secondary cell wall. In this last group there is the gene Eucalyptus Cellulose Synthase 3 (EgCesA3), the most expressed CesA gene during xylogenesis [2]. Besides, knockout experiments proved that the AtCesA7 (EgCesA3 ortholog in Arabidopsis thaliana) activity is essential for the xylem formation and for plant vertical growth [3].

In front of these evidences, the $E g C e s A 3$ gene had it expression pattern evaluated in leaf and xylem tissues among the three most economic important Eucalyptus species in Brazil: E. grandis, E. globulus andE. urophyla.

As demonstrated in this work, the expression experiment provided enough information about the $\operatorname{EgCes} A 3$ function, that's why this gene was chosen to be overexpressed in model plants (Arabidopsis thaliana and

\footnotetext{
*Correspondence: goncalo@unicamp.br

${ }^{1}$ State University of Campinas - UNICAMP, Brazil

${ }^{2}$ International Paper

Full list of author information is available at the end of the article
}

Nicotiana tabacum). It's expected increased cellulose content in the transgenic plants xylem.

\section{Material and methods}

The EgCesA3 expression pattern was examined trough qRT-PCR and Northern-Blot in xylem and leaf from the tree most commercially important Eucalyptus species: $E$. grandis,E. urophyla and $E$. globulus. The qRT-PCR was performed using SYBR Green and amplicons with approximated size of $100 \mathrm{pb}$. On the other hand, the Northern-Blot was made with probes containing phosphorous-32 radioactive.

To create transgenic plants with improved cellulose content this work overexpressed the gene $\operatorname{EgCesA3}$ under the control of the CaMV $35 \mathrm{~S}$ promoter in $A$. thaliana and Nicotiana tobacum trough Agrobacterium transformation by floral-spray.

\section{Results and discussion}

The results show that the $E g C e s A 3$ is strongly more expressed in xylem than in leaves among the three most important economical Eucalyptus species for the Brazilian forest industry (Fig. 1). This data corroborate to the theory that this gene is related to the secondary cell wall formation during the xylem development.

However, it's necessary to mention that the gene expression data obtained through the northern-blot related to the E. globulus leaf can't be analyzed. This because the amount of RNA used in this sample was different from the others. It can be seen through the rRNA amounts in the RNA electrophoresis (Fig. 1). 




Figure 1 Eucalyptus Cellulose Synthase 3 expression pattern. On the top, expression pattern analyzed trough qRT-PCR and, below, the expression analyzed trough Northern-Blot. The tissues studied were leaves and xylem from three different Eucalyptus species: E. globulus, E. grandis and E. urophyla.

Besides, comparing the EgCesA3 expression pattern between the xylem from the three species studied, it's possible to conclude that should exist a difference: the $E g C e s A 3$ gene is apparently more expressed in $E$. grandis and E. urophyla xylem than in E. globulus xylem (Fig. 1). However, this conclusion isn't distant from doubts: the problem is the large error bars that happened in the experiment. In order to solve it, the qRTPCR repetition is being carried on.

In front of the EgCesA3 rolein the secondary cell wall synthesis, this gene was overexpressed in model plants (Fig. 2). The genetic modified plants were successfully obtained. Thus, after the generation advance, the homozygous transgenic plants will be evaluated to measure the cell wall chemical composition and morphology.

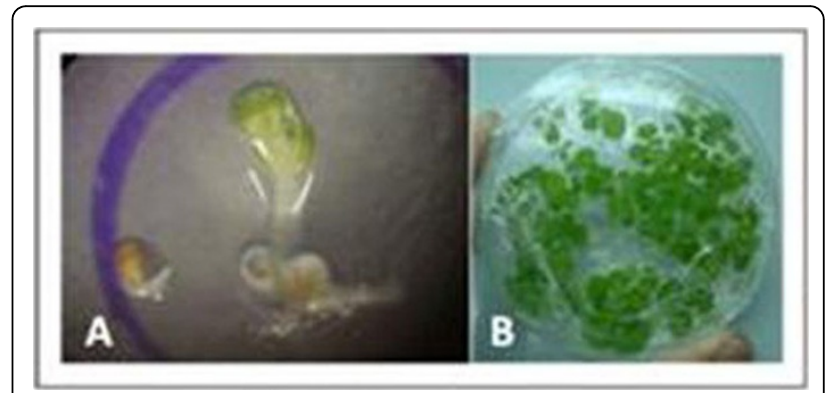

Figure 2 Transgenic model plants overexpressing the Eucalyptus grandis Cellulose Synthase 3 gene. In "A" it's possible to see one transgenic $A$. thaliana near a nother non-transgenic seeds being selected in the media containing hygromycin. In "B" it's shown transgenic Nicotiana tabacum growing in selection media with hygromycin. 


\section{Conclusion}

The Eucalyptus Cellulose Synthase 3 function in the secondary cell wall synthesis was confirmed by this work;

The cellulose content variation trough the species studied should be a consequence of the Eucalyptus CesA3 expression level;

Transgenic $A$. thaliana and $N$. tabacum overexpressing the $E g C e s A 3$ gene were successfully obtained. The transgenic plants analyses are being performed; however it's already possible to notice, by empirical view, growth improvement in the transgenic plants in comparison to the wild type.

\section{Author details}

${ }^{1}$ State University of Campinas - UNICAMP, Brazil. ${ }^{2}$ International Paper.

Published: 13 September 2011

\section{References}

1. Doblin MS, Kurek I, Jacob-Wilk D, Delmer DP: Cellulose biosynthesis in plants: from genes to rosettes. Plant \& cell physiology 2002, 43:1407-20.

2. Ranik M, Myburg A: a: Six new cellulose synthase genes from Eucalyptus are associated with primary and secondary cell wall biosynthesis. Tree physiology 2006, 26:545-56.

3. Brown DM, Zeef LAH, Ellis J, Goodacre R, Turner SR: Identification of Novel Genes in Arabidopsis Involved in Secondary Cell Wall Formation Using Expression Profiling and Reverse Genetics. Cellulose 2005, 17:2281-2295.

doi:10.1186/1753-6561-5-S7-P167

Cite this article as: Marques et al.: Transgenic Arabidopsis thaliana and Nicotiana tabacum overexpressing the Eucalyptus grandis Cellulose Synthase 3 and its expression pattern in different Eucalyptus species and tissues. BMC Proceedings 2011 5(Suppl 7):P167.

\section{Submit your next manuscript to BioMed Central} and take full advantage of:

- Convenient online submission

- Thorough peer review

- No space constraints or color figure charges

- Immediate publication on acceptance

- Inclusion in PubMed, CAS, Scopus and Google Scholar

- Research which is freely available for redistribution

Submit your manuscript at www.biomedcentral.com/submit 